\title{
Keterampilan meneliti yang dimiliki mahasiswa prodi pendidikan biologi se-Wilayah III Cirebon
}

\author{
Djohar Maknun $^{1}{ }^{*}$, Ria Yulia Gloria ${ }^{1}$, Jajang Aisyul Muzakki ${ }^{2}$ \\ ${ }^{1}$ Program Studi Tadris Biologi, Institut Agama Islam Negeri Syekh Nurjati Cirebon. \\ ${ }^{2}$ Program Studi Pendidikan Islam Anak Usia Dini, Institut Agama Islam Negeri Syekh Nurjati Cirebon. \\ Jalan Perjuangan Bypass Karya Mulya, Sunyaragi, Kec. Kesambi, Kota Cirebon, Jawa Barat 45132, Indonesia \\ * Corresponding Author. Email: maknundjohar@gmail.com
}

Received: 21 November 2019; Revised: 5 December 2019; Accepted: 4 May 2020

\begin{abstract}
Abstrak: Keterampilan meneliti meliputi keterampilan dasar, yaitu observasi, mengukur, klasifikasi, komunikasi, membuat inferensi, membuat prediksi, dan keterampilan terintegrasi berupa menafsirkan data, mengendalikan variabel, membuat definisi operasional, dan merumuskan hipotesis, dan melaksanakan eksperimen. Secara umum keterampilan meneliti meliputi keterampilan merancang, melaksanakan, dan melaporkan hasil penelitian. Tujuan penelitian ini untuk meningkatkan keterampilan meneliti mahasiswa S1 Program Studi Pendidikan Biologi Se-wilayah III Cirebon. Penelitian ini menggunakan metode deskriptif kuantitatif. Teknik analisis data menggunakan statistik deskriptif. Instrumen penelitian menggunakan tes dan kuesioner. Sampel diambil secara acak sederhana. Hasil penelitian ini adalah rataan tingkat penguasaan keterampilan meneliti merancang tercapai sebesar 51,3\%, melaksanakan penelitian sebesar $55,21 \%$, dan melaporkan hasil penelitian 62,82\%. Keterampilan meneliti kurang diberikan pelatihan pada saat pembelajaran, hanya $43,8 \%$ dosen pembimbing praktikum yang memberikan pembekalan keterampilan meneliti. Kesimpulan penelitian menunjukkan bahwa keterampilan meneliti mahasiswa S-1 Prodi Pendidikan Biologi Se-wilayah III Cirebon masih tergolong dalam kategori kurang.
\end{abstract}

Kata Kunci: keterampilan meneliti; pendidikan biologi; Wilayah III Cirebon

\section{Research skills held by biology education study program students in Region III Cirebon}

\begin{abstract}
Research skills include basic skills, namely observation, measuring, classification, communication, making inferences, making predictions, and integrated skills in the form of interpreting data, controlling variables, making operational definitions, and formulating hypotheses, and carrying out experiments. In general, research skills include the skills of designing, implementing, and reporting the results of research. The purpose of this study was to improve the research skills of undergraduate students in the Biology Education Study Program in Region III Cirebon. This research uses quantitative descriptive methods. Data analysis techniques using descriptive statistics. Research instruments using tests and questionnaires. Samples are taken at random. The results of this study are the average mastery level of researching design skills reached $51.3 \%$, carrying out research amounting to $55.21 \%$, and reporting research results of $62.82 \%$. Research skills were not given training while learning, only $43.8 \%$ of practicum supervisors provided research skills. The conclusion of the study shows that the research skills of undergraduate students of Biology Education Study Program in Region III Cirebon are still classified in the inadequate category.
\end{abstract}

Keywords: research skills; biology education; Region III Cirebon

How to Cite: Maknun, D., Gloria, R., \& Muzakki, J. (2020). Keterampilan meneliti yang dimiliki mahasiswa prodi pendidikan biologi se-wilayah III Cirebon. Jurnal Inovasi Pendidikan IPA, 6(1), 39-48. doi:https://doi.org/10.21831/jipi.v6i1.28251

\section{PENDAHULUAN}

Keterampilan meneliti menjadi tuntutan dalam Kurikulum 2013. Hal ini termuat dalam Peraturan Menteri Pendidikan Dan Kebudayaan Nomor 22 Tahun 2016 tentang Standar Proses Pendidikan Dasar dan Menengah (2016). Intisari isi dalam Permendikbud tersebut menyatakan bahwa pembelajaran hendaknya berbasis penyingkapan/penelitian (discovery/inquiry learning) dan pemecahan masalah yang 
menghasilkan karya atau produk (project-based learning). Adapun aktivitas yang dapat dilakukan, seperti: mengamati, menanya, mencoba, menalar, menyaji, dan mencipta.

Berkaitan dengan keterampilan meneliti, Peraturan Menteri Pendidikan dan Kebudayaan Republik Indonesia Nomor 65 Tahun 2013 tentang Standar Proses Pendidikan Dasar dan Menengah (2013) menyebutkan bahwa sasaran pembelajaran biologi mencakup pengembangan ranah keterampilan, pengetahuan, dan sikap. Biologi sebagai sains mengedepankan aspek minds on, hands on, dan hearts on. Aspek tersebut merupakan kemampuan menggunakan pikiran untuk membangun konsep melalui pengalaman langsung yang disertai dengan sikap ilmiah. Untuk memperkuat pendekatan ilmiah (scientific) perlu diterapkan pembelajaran berbasis penelitian. Untuk mendorong kemampuan peserta didik menghasilkan karya kontekstual, baik individual maupun kelompok maka sangat disarankan menggunakan pendekatan pembelajaran yang menghasilkan karya berbasis pemecahan masalah (Peraturan Menteri Pendidikan dan Kebudayaan Nomor 22 Tahun 2016 tentang Standar Proses Pendidikan Dasar dan Menengah, 2016).

Hal ini selaras dengan "21st Century Partnership Learning Framework". Kompetensi yang harus dimiliki oleh sumber daya manusia abad 21, yaitu: kemampuan memecahkan masalah (Problem Solving Skills) dan kemampuan berkomunikasi (Communication Skills) Partnership for 21st century Skill (Wahyudi et al., 2015). Oleh karena itu, pendidikan hendaknya berhubungan erat dengan masalah yang ada di dunia nyata sehingga pendidik diharapkan tidak hanya menanyakan "bagaimana", tetapi "mengapa". Semua itu agar peserta didik mampu menemukan konsep sendiri untuk mengatasi masalah.

Persoalannya atau kenyataan di lapangan pada implementasi Kurikulum 2013 ini belum sesuai dengan harapan, terutama dalam pembelajaran penelitian. Rendahnya hasil pembelajaran sains di sekolah Indonesia didukung oleh hasil studi PISA (Programme for International Student Assessment) dan TIMSS (Trends in International Mathematics and Sciences Study). PISA merupakan evaluasi yang dilakukan pada beberapa negara. Evaluasi ini dapat berupa tes maupun kuisoner. Evaluasi yang dilakukan, meliputi: sains, membaca, dan matematika. Indonesia telah mengikuti PISA sejak tahun 2000 hingga 2012 dan terakhir adalah pada tahun 2015. Tahun 2000 diikuti oleh 41 negara dan Indonesia mendapat peringkat ke-39 dengan skor 367 untuk studi literasi matematika. Pada tahun 2003, PISA diikuti oleh 40 negara dan Indonesia mendapat peringkat ke-38 dengan skor 360 untuk literasi matematika. Tahun 2006, PISA diikuti oleh 57 negara dan menempatkan Indonesia pada posisi ke-50 dengan skor 391 untuk literasi matematika. Tahun 2009, PISA diikuti 65 negara dan Indonesia mendapat peringkat ke-60 (Pratiwi, 2019; Wu, 2011).

Laporan terbaru tentang PISA ternyata performa Indonesia menurun, yaitu dari PISA $2015 \mathrm{ke}$ PISA 2018, terutama pada indikator kemampuan kinerja sains. Kemampuan kinerja sains menurun dari skor 403 di tahun 2015 menjadi skor 396 di tahun 2018, dan masih berada di peringkat 71 dari 79 negara (OECD, 2019). Selain PISA, terdapat evaluasi serupa yang bernama TIMSS (Trends in International Mathematics and Science Study). Tahun 2009, TIMSS menempatkan Indonesia pada peringkat 34 dari 45 negara. Pre test pada siswa SMPN 1 Ungaran menunjukkan bahwa 55\% siswa hanya mampu menyelesaikan soal matematika bertipe PISA pada level 3, dan 45\% siswa hanya mampu menyelesaikan soal di bawah level 3 (TIMSS \& PIRLS, 2019).

Dari beberapa hasil penelitian tersebut, tentunya hal tersebut kurang sejalan dengan konsep Biological Science Curriculum Study (BSCS). Pada konsep BSCS meminta siswa untuk berlatih menjadi peneliti. BSCS merekomendasikan model penelitian biologi hendaknya dirancang untuk mengajarkan proses-proses biologi. Proses biologi yang dimaksud berupa: memengaruhi cara siswa dalam memproses informasi, berkomitmen untuk melakukan penelitian ilmiah, membuka pemikiran, berlatih meneguhkan pendapat serta mengajarkan kerja sama antara siswa dengan siswa dan antara siswa dengan guru. BSCS menekankan isi dan proses. Isi berhubungan dengan materi esensial yang perlu diberikan saat ini. Proses berhubungan dengan penelitian sains. Tujuan terpenting metode ini adalah memberi gambaran dan pemahaman terkait masalah-masalah sains terbaru serta pengukurannya (Bybee, 2009).

Selain itu, kemampuan meneliti juga harus dimiliki oleh para akademisi. Berdasarkan pengamatan, mahasiswa S-3 juga mengalami permasalahan dalam meneliti. Data dikumpulkan melalui wawancara kepada 9 staf akademik dan 14 mahasiswa semester akhir. Hasil analisis menunjukkan bahwa pengembangan yang dilakukan dapat memperdalam metakognisi penelitian sehingga membantu mahasiswa untuk bertindak dan berpikir seperti peneliti. Penelitian studi kasus ini diharapkan dapat menentukan keefektifan penerapan model konseptual dan pengembangan keterampilan meneliti (Willison \& Buisman-Pijlman, 2016). 
Penelitian Szostak (2013) menyimpulkan bahwa seorang peneliti harus memiliki kemampuan interdisipliner. Adapun karakteristik interdisipliner, yaitu (a) interdisipliner berfokus pada masalah atau pertanyaan tertentu untuk dijawab oleh satu disiplin ilmu; (b) interdisipliner memanfaatkan wawasan penelitian khusus yang dilakukan oleh komunitas peneliti dengan seperangkat pertanyaan, konsep, teori, dan metode; (c) interdisipliner mengevaluasi hasil penelitian khusus; (d) interdisipliner menggunakan banyak teori dan metode. Adanya kesadaran bahwa semua teori, metode, dan disiplin ilmu berguna untuk beberapa tujuan walaupun juga memiliki kelemahan; (e) para ahli interdisipliner menghargai bahwa setiap disiplin dicirikan oleh perspektif disipliner yang berkembang; dan (f) interdisipliner mengintegrasikan elemen wawasan disipliner terbaik untuk menghasilkan apresiasi yang lebih komprehensif dan seringkali lebih tepat terhadap masalah yang sedang dihadapi. Para interdisipliner sering menekankan integrasi sebagai elemen pendefinisian interdisipliner. Interdisciplinarity menuntut keterlibatan serius dengan berbagai disiplin ilmu: pemahaman tentang terminologi, perspektif, teori, dan metode yang memungkinkan seseorang untuk menempatkan wawasan tertentu yang mungkin muncul.

Secara umum, seorang peneliti hendaknya memiliki kemampuan dalam: (1) menulis laporan; (2) merumuskan pertanyaan/hipotesis; (3) merancang eksperimen, komunikasi lisan; (4) manajemen waktu; (5) menemukan referensi; dan (6) mengkritisi referensi tersebut (Loveys et al., 2014). Adapun indikator keterampilan meneliti secara umum, meliputi: menulis, berbicara, mengumpulkan informasi, mengevaluasi informasi, berhitung, kerja tim, bekerja mandiri, manajemen proyek, manajemen waktu, menyelesaikan masalah, serta berpikir kritis. Adapun indikator keterampilan meneliti secara khusus, meliputi: merancang penelitian, menentukan sampel, memilih responden, mengumpulkan data, statistika Biologi, pelaporan, dan presentasi (Davidson \& Palermo, 2015). Mahasiswa hendaknya juga memiliki keterampilan, seperti: memprediksi, berhipotesis, mengidentifikasi dan mengendalikan variabel, serta merekam data (Karamustafaoğlu, 2011).

Pada dasarnya, meneliti bukanlah hal yang rumit. Namun demikian, banyak mahasiswa yang belum paham. Hal ini bisa jadi karena mahasiswa kurang membaca dan atau merasa ragu-ragu dengan informasi yang diperoleh. Biasanya, mahasiswa memperoleh informasi melalui pembelajaran di kelas. Supaya mahasiswa tidak merasa ragu, pengajar harus dapat memilih metode pembelajaran yang tepat. Salah satu metode pembelajaran yang dapat meningkatkan keterampilan meneliti adalah Based Learning Projects (BLP) (Chu et al., 2008).

Dalam belajar biologi, keterampilan meneliti memegang peranan penting. Keterampilan meneliti dapat dicapai melalui pembelajaran praktikum. Pendekatan keterampilan meneliti memberikan pengalaman langsung dan pengalaman pertama kepada peserta didik, sehingga mampu mengubah persepsi peserta didik tentang hal-hal penting. Seorang guru hendaknya dapat membantu siswa untuk memiliki keterampilan meneliti. Guru atau tenaga pendidik yang kompeten sangat menjamin perbaikan kualitas sumber daya manusia di sebuah negara, sehingga tidak berlebihan jika mengatakan bahwa guru memang harus memiliki kompetensi yang luar biasa. Akan tetapi, kenyataan di lapangan menunjukkan bahwa guru belum memiliki kompetensi yang memadai, terutama dalam hal mendesain pembelajaran dan penelitian.

Fakta lain menunjukkan bahwa guru belum memiliki kompetensi yang cukup dalam hal melaksanakan penelitian. Fakta ini terlihat dari hasil studi pendahuluan yang dilakukan Leonard (2015) melaporkan bahwa hampir 70\% guru yang disurvei belum memiliki pengetahuan yang benar mengenai konsep masalah dan penelitian. Bahkan hampir $90 \%$ guru tidak pernah melakukan kegiatan penelitian. Hal ini mengakibatkan hampir 100\% guru tidak pernah melakukan publikasi mengenai hasil penelitian. Hammersley (1993) mengungkapkan, sebenarnya antara penelitian dan pembelajaran merupakan bagian yang tidak terpisahkan, sehingga penelitian juga merupakan kompetensi inti yang seharusnya dikuasai oleh para guru.

Mahasiswa yang notabene sebagai calon guru hendaknya memiliki keterampilan meneliti. Hal ini karena keterampilan meneliti merupakan komponen penting, terutama pada pendidikan sains (Kapon, 2016). Namun demikian, mahasiswa belum memiliki keterampilan meneliti secara memadai. Semua itu dapat diketahui dari penelitian. Salah satunya karena Perguruan Tinggi di Indonesia belum mempersiapkan lulusannya untuk memiliki keterampilan meneliti yang baik (Aloysius, 2016). Demi menghasilkan guru yang berkualitas, perlu dilakukan peningkatan keterampilan meneliti para mahasiswa S-1 Pendidikan Biologi sebagai calon guru melalui pembelajaran praktikum.

Mahasiswa sebagai peneliti adalah pedagogi aktif yang menekankan pada proses penelitian dan penyelidikan. Penelitian ini mencakup cara untuk mempromosikan hubungan penelitian-pengajaran 
dengan mengembangkan apresiasi siswa terhadap penelitian. Penelitian ini juga dapat melibatkan: (1) penggunaan pendekatan pengajaran dan pembelajaran yang menyimulasikan proses penelitian; (2) memberikan tugas yang melibatkan penelitian atau elemen proses penelitian lain; (3) memberikan siswa pengalaman langsung berupa konsultasi berbasis penelitian atau proyek (Anderson \& Priest, 2012). Berdasarkan uraian tersebut, maka peneliti ingin mendeskripsikan keterampilan meneliti yang dimiliki oleh mahasiswa Prodi Pendidikan Biologi se-wilayah III Cirebon.

\section{METODE}

Data diperoleh melalui tes dan kuesioner. Tes yang dilakukan berupa memberi tugas kepada mahasiswa. Tugas tersebut memuat materi terkait keterampilan meneliti yang meliputi: merancang penelitian, melaksanakan penelitian dan melaporkan hasil penelitian (Bazeley, 2010). Mahasiswa melakukan tugas lalu diamati sehingga instrumen yang digunakan berupa pedoman observasi. Pedoman ini telah divalidasi secara kontens dan oleh pakar. Pengujian validitas tiap butir instrumen menggunakan analisis item menunjukkan bahwa 27 butir soal yang diujicobakan valid dengan indeks validitas 0,26 sampai dengan 0,90. Validitas secara keseluruhan adalah 0,46 dengan $r_{t}=0,30$. Secara umum dalam penentuan tingkat reliabilitas dengan menggunakan rumus Cronbach's Alpha, instrumen penelitian memiliki indeks reliabilitas $>0,70$ (sangat baik). Pengolahan data dilakukan dengan komputer program SPSS 18.0.

Penelitian ini melibatkan mahasiswa Program Studi Pendidikan Biologi di wilayah III Cirebon yang berasal dari Universitas Majalengka, Universitas Wiralodra Indramayu, Universitas Kuningan dan IAIN Syekh Nurjati Cirebon. Total responden sebanyak 91 mahasiswa yang terdiri atas $87,9 \%$ mahasiswa laki-laki dan $12,1 \%$ mahasiswa perempuan. Responden lainnya adalah 42 orang dosen pengampu praktikum mata kuliah di perguruan tinggi tersebut, terdiri atas dosen laki-laki 33,3\% dan dosen perempuan $66,7 \%$.

Data dianalisis secara kuantitatif deskriptif menggunakan Likert scale score untuk memperoleh gambaran pengetahuan mahasiswa tentang keterampilan meneliti. Teknik pengambilan sampel secara acak sederhana. Responden diberikan seperangkat tes dan kuesioner yang terkait dengan kompetensi keterampilan meneliti. Selanjutnya data dianalisis menggunakan statistik deskriptif untuk mengkaji kompetensi keterampilan meneliti mahasiswa.

\section{HASIL DAN PEMBAHASAN}

Data hasil penelitian menunjukkan bahwa keterampilan merancang, melaksanakan dan melaporkan penelitian tercapai berturut-turut pada angka 51,3\%,55,2\%, dan 62,8\%. Gambar 1 menunjukkan nilai pencapaian per aspek keterampilan meneliti mahasiswa S-1 Program Studi Pendidikan Biologi di Wilayah III Cirebon.
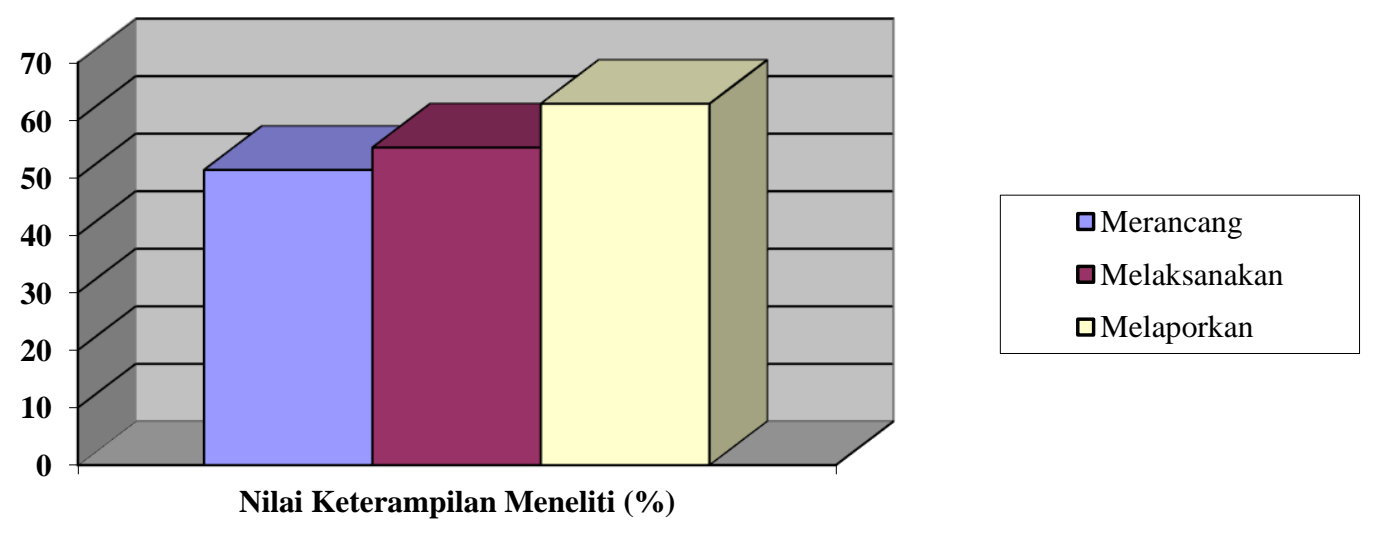

Gambar 1. Nilai Pencapaian Keterampilan Meneliti

Keterampilan mengidentifikasi variabel random atau acak dalam suatu penelitian mencapai angka yang paling rendah yaitu hanya $7,7 \%$, selanjutnya diikuti oleh keterampilan menetapkan prosedur pengumpulan data suatu penelitian mencapai $15,5 \%$, keterampilan merancang jenis data yang harus dihimpun dalam suatu penelitian yaitu $19,8 \%$ dan merancang ukuran sampel yang diperlukan dalam suatu 
penelitian mencapai angka 33,0\%. Pencapaian angka yang paling tinggi yaitu pada keterampilan menetapkan hipotesis sebesar 91,2\% (Gambar 2).

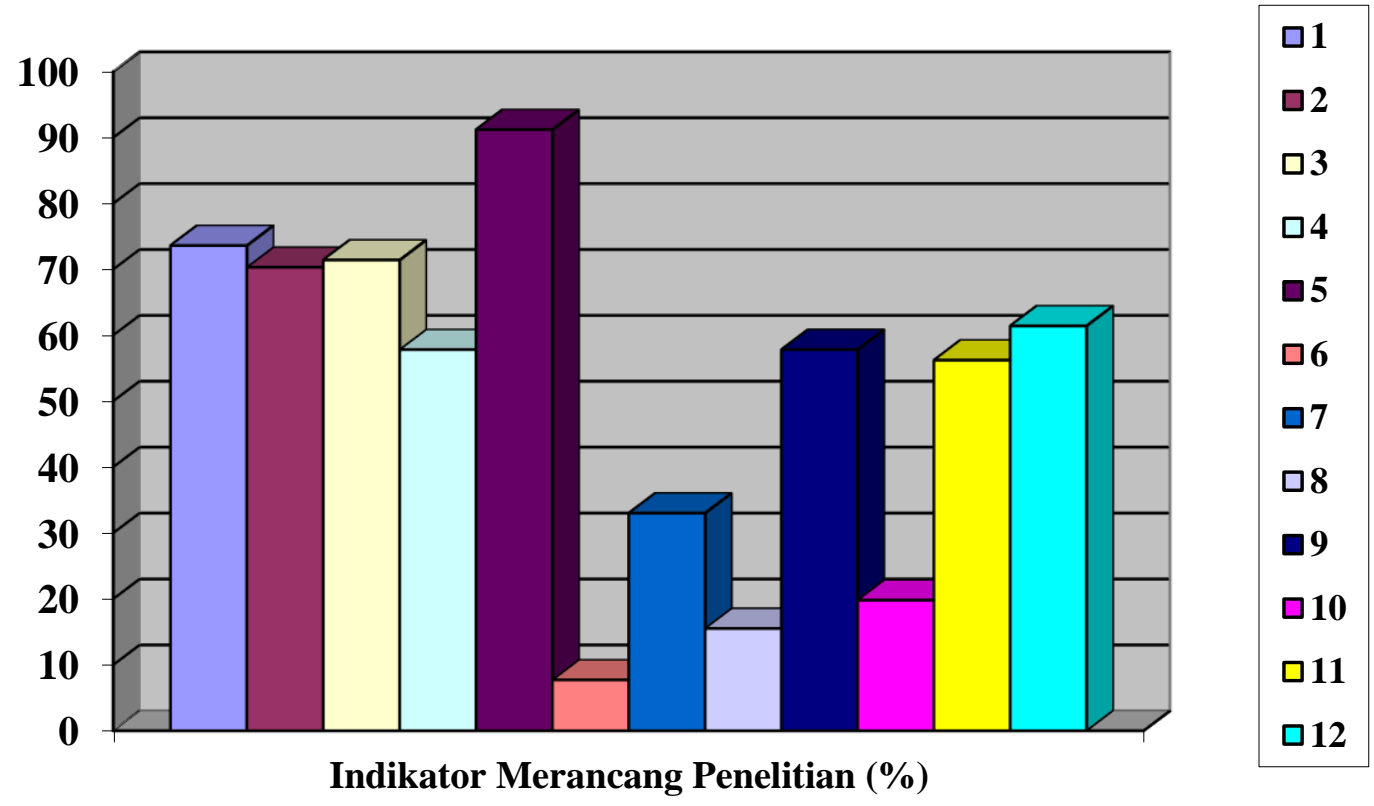

Gambar 2. Nilai Pencapaian Indikator Keterampilan Merancang Penelitian

Adapun penjelasan indikator tersebut, yaitu: (1) menetapkan variabel bebas sebagai faktor perlakuan dalam penelitian; (2) mengidentifikasi hubungan antara variabel bebas dan variabel terikat dalam suatu penelitian; (3) mengemukakan latar belakang pentingnya dilakukan suatu penelitian; (4) merancang pengendalian variabel pengganggu (suppressed variable) menjadi variabel kendali (control variable) dalam suatu; (5) eksperimen; (6) mengidentifikasi variabel random atau acak dalam suatu penelitian; (7) menetapkan hipotesis penelitian; (8) merancang ukuran sampel yang diperlukan dalam suatu penelitian; (9) menetapkan prosedur pengumpulan data suatu penelitian; (10) merancang rangkaian peralatan untuk suatu penelitian; (11) merancang jenis data yang harus dihimpun dalam suatu penelitian; dan (12) merancang penyajian data hasil dari suatu penelitian.

Merujuk paada Tabel 1 dapat dilihat bahwa rataan pencapaian aspek merancang keterampilan meneliti adalah 51,30\%, dengan nilai minimum 7,70\% dan maksimum 91,20\%.

Tabel 1. Statitistik Deskriptif Aspek Merancang Penelitian

\begin{tabular}{|c|c|c|c|c|c|c|}
\hline & $\mathrm{N}$ & Minimum & Maximum & Mean & Std. Deviation & Variance \\
\hline Merancang & 12 & 7,70 & 91,20 & 51,3083 & 26,24114 & 688,597 \\
\hline Valid N (listwise) & 12 & & & & & \\
\hline
\end{tabular}

Keterampilan mengatur perlakuan dalam eksperimen sesuai ancangan mencapai angka yang paling rendah, yaitu $46,1 \%$, selanjutnya diikuti oleh keterampilan menyusun rangkaian peralatan eksperimen/penelitian sesuai rancangan mencapai $48,3 \%$. Pencapaian angka yang paling tinggi yaitu pada keterampilan menjaga kestabilan kondisi lingkungan jika melakukan eksperimen sebesar $69,0 \%$. Nilai pencapaian indikator melaksanakan penelitian ditunjukkan oleh Gambar 3.

Adapun maksud setiap nomor merujuk pada: (1) menyusun rangkaian peralatan eksperimen/penelitian sesuai rancangan; (2) mengatur perlakuan dalam eksperimen sesuai rancangan; (3) menangani variabel penekan/pengganggu atau variabel asing sesuai rancangan; (4) melakukan pengukuran untuk menghimpun data sesuai rancangan; (5) mencatat seluruh data eksperimen sesuai rancangan; (6) menjaga kestabilan kondisi lingkungan jika melakukan eksperimen; serta (7) mengamati dan mencatat data yang menunjukkan penyimpangan bila melakukan eksperimen.

Tabel 2 menunjukkan bahwa nilai rataan aspek keterampilan melaksanakan penelitian mencapai angka $55,21 \%$, nilai minimum $46,1 \%$ dan maksimum $69,00 \%$. Nilai statitistik lainnya dapat dilihat pada Tabel 2. 
Jurnal Inovasi Pendidikan IPA, 6 (1), 2020 - 44

Djohar Maknun, Ria Yulia Gloria, Jajang Aisyul Muzakki
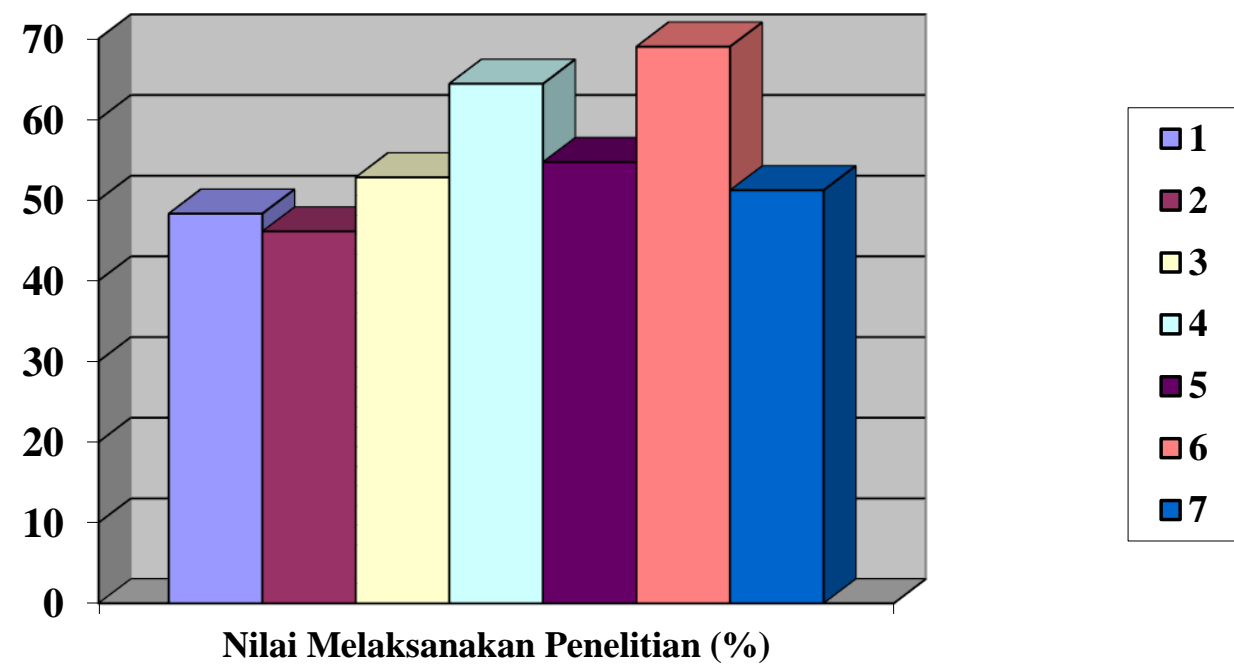

Gambar 3. Nilai Pencapaian Indikator Keterampilan Melaksanakan Penelitian

Tabel 2. Statitistik deskriptif aspek melaksanakan penelitian

\begin{tabular}{lllllll}
\hline & N & Minimum & Maximum & Mean & Std. Deviation & Variance \\
\hline Melaksanakan & 7 & 46,10 & 69,00 & 55,2143 & 8,44106 & 71,251 \\
Valid N (listwise) & 7 & & & & & \\
\hline
\end{tabular}

Keterampilan meneliti pada aspek melaporkan hasil penelitian, indikator paling rendah sebesar 40,2\% terjadi pada keterampilan menarik simpulan umum hasil penelitian berdasarkan hasil observasi dan generalisasi data/hasil analisis statistika, berikutnya diikuti keterampilan menyajikan hasil suatu penelitian yang telah dilakukan dalam bentuk diagram, tabel ataupun grafik tercapai pada nilai 51,2\%. Keterampilan meneliti dengan indikator menuangkan hasil, pembahsan, dan simpulan suatu penelitian dalam suatu laporan secara tertulis mencapai nilai tertinggi yaitu $82,8 \%$, dan diikuti oleh keterampilan menyajikan pembaasan suatu hasil penelitian sebesar 77,0\%. Nilai pencapaian indikator melaksanakan penelitian dapat dilihat pada Gambar 4.

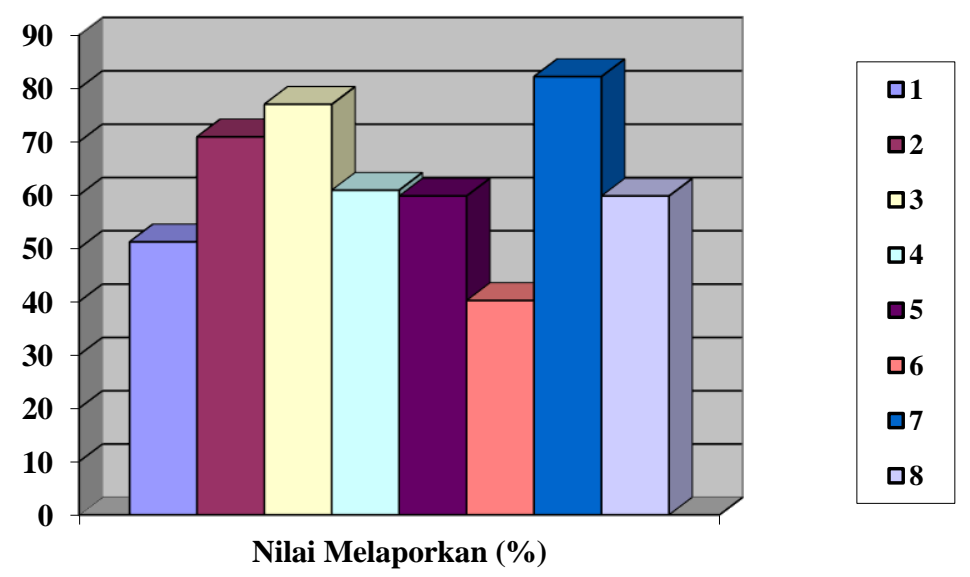

Gambar 4. Nilai Pencapaian Indikator Keterampilan Melaporkan Hasil Penelitian

Berikut ini penjelasan yang dirujuk pada nomor: (1) menyajikan hasil suatu penelitian yang telah dilakukan dalam bentuk diagram, tabel ataupun grafik; (2) menyajikan simpulan data hasil suatu penelitian; (3) menyajikan pembahasan suatu hasil penelitian; (4) menetapkan kebenaran hasil penelitian; (5) menetapkan kebenaran hasil penelitian; (6) menarik simpulan umum hasil penelitian berdasarkan hasil observasi dan generalisasi data/hasil analisis statistika; (7) menuangkan hasil, pembahasan, dan simpulan suatu penelitian dalam suatu laporan secara tertulis; dan (8) mendiseminasikan hasil, pembahasan, dan simpulan suatu penelitian, baik pada presentasi kelas maupun seminar.

Aspek keterampilan melaporkan hasil penelitian mencapai nilai rataan sebesar $62,82 \%$. Nilai minimum pada aspek ini pada angka 40,20\% dan maksimum 82,80\% (Tabel 3). 
Jurnal Inovasi Pendidikan IPA, 6 (1), 2020 - 45

Djohar Maknun, Ria Yulia Gloria, Jajang Aisyul Muzakki

Tabel 3. Statitistik Deskriptif Aspek Melaporkan Hasil Penelitian Penelitian

\begin{tabular}{lllllll}
\hline & N & Minimum & Maximum & Mean & Std. Deviation & Variance \\
\hline Melaporkan & 8 & 40,20 & 82,80 & 62,8250 & 13,80567 & 190,596 \\
Valid N (listwise) & 8 & & & & & \\
\hline
\end{tabular}

Tabel 4 menunjukkan bahwa secara menyeluruh rataan aspek keterampilan meneliti mahasiswa S-1 Program Studi Pendidikan Biologi di Wilayah III Cirebon baru mencapai nilai 55,73\%.

Tabel 4. Nilai pencapaian rataan keterampilan meneliti

\begin{tabular}{|c|c|c|c|c|c|c|}
\hline & & Minimum & Maximum & Mean & Std. Deviation & Variance \\
\hline KetMeneliti & 27 & 7,70 & 91,20 & 55,7333 & 19,58752 & 383,671 \\
\hline Valid N (listwise) & 27 & & & & & \\
\hline
\end{tabular}

Survei dilakukan juga pada 42 responden, terdiri dari dosen laki-laki 33,3\% dan dosen perempuan $66,7 \%$, yang mengampu mata kuliah berpraktikum. Hasil dari analisis angket yang didistribusikan diperoleh data sebesar $43,8 \%$ responden menyatakan selalu memberikan latihan "keterampilan meneliti" pada saat kegiatan praktikum mata kuliah. Hanya sekitar 30,6\% - 39,2\% responden memberikan latihan "merancang penelitian", 31,4\% - 42,1\% memberikan latihan "melaksanakan penelitian" dan 34,5\% $46,1 \%$ dosen memberikan latihan "melaporkan hasil penelitian pada saat kegiatan praktikum mata kuliah.

Dari aspek merancang penelitian, menunjukkan bahwa indikator "keterampilan" merancang pengendalian variabel pengganggu (suppressed variable) menjadi variabel kendali (control variable) dalam suatu eksperimen" sangat jarang dilatihkan dalam kegiatan praktikum. Hasil dari studi pendahuluan, indikator tersebut hanya mencapai $10 \%$ respondens yang menyatakan selalu, dan $38 \%$ yang menyatakan sering. Untuk aspek melaksanakan penelitian pada indikator keterampilan "menangani variabel penekan/pengganggu atau variabel asing sesuai rancangan" responden menyatakan yang menyatakan selalu hanya $14 \%$ dan sering $26 \%$ dalam memberikan latihan pada indikator tersebut. Indikator pada aspek melaporkan hasil penelitian yaitu keterampilan "mendiseminasikan hasil, pemba-hasan, dan simpulan suatu penelitian, baik pada presentasi kelas maupun seminar" respondens menyata-kan selalu $33 \%$ dan sering $26 \%$. Hasil angket juga menunjukkan bahwa pada praktikum model proyek yang diperkaya, respondens yang menyatakan selalu $10 \%$ dan sering $13 \%$. Artinya dalam kegiatan praktikum strategi pembelajaran model proyek masih sangat jarang dilakukan oleh para dosen di Jurusan Pendidikan Biologi pada perguruan tinggi Wilayah III Cirebon.

Dari hasil analisis ini dapat disimpulkan bahwa keterampilan meneliti mahasiswa S-1 Jurusan Pendidikan Biologi masih perlu ditingkatkan. Perlu juga memaksimalkan pengelolaan praktikum yang ada dengan memberikan latihan keterampilan meneliti. Mahasiswa dibekali berbagai aspek keterampilan meneliti dan memahami betul tentang penelitian. Penelitian merupakan upaya mengumpulkan informasi, mendokumentasikan fakta, dan mencari informasi lalu dianalisis dan interpretasi data untuk memahami sebuah fenomena. Proses penelitian bersifat sistematis (Williams, 2011). Dapat juga dikatakan, penelitian sebagai upaya pencarian kebenaran terhadap pengetahuan yang bertujuan untuk mendeskripsikan suatu fenomena yang dilakukan oleh orang berkeahlian. Namun demikian, selama ini terdapat anggapan yang keliru terkait penelitian. Pertama, peneliti selalu diidentikkan dengan orang yang pandai. Sebenarnya, peneliti juga harus memiliki kreativitas serta kemampuan interaksi yang baik. Seorang peneliti hendaknya ekspresif. Kedua, kemampuan dalam memahami suatu ilmu akan sangat berdampak pada pengembangan dan kebermanfaatan ilmu itu sendiri. Ketiga, tidak adanya dukungan dari pengambil kebijakan akan berpengaruh pada perkembangan dan kebermanfaat ilmu.

Selanjutnya perlu dikembangkan instrumen penilaian yang berbasis autentik untuk mengevaluasi kegiatan praktikum yang berorientasi penelitian. Hal ini sesuai hasil penelitian dari Gobaw \& Atagan (2016) yang bertujuan untuk mengevaluasi kinerja keterampilan laboratorium mahasiswa sarjana biologi di Etiopia. Berdasarkan analisis disarankan agar dilakukan penilaian berbasis kinerja, ujian tulis, pengembangan profesional keterampilan kinerja laboratorium biologi serta pengetahuan tentang cara menilai kemampuan kinerja laboratorium.

Menurut Leeming et al. (1993) menyatakan bahwa sangat penting untuk mengubah perilaku dan sikap dalam menjaga kualitas lingkungan. Oleh karenanya harus mencari informasi yang relevan dalam hal ini. Pembelajaran ekologi yang secara langsung berkaitan dengan jenis sikap dan perilaku lingkungan mencoba mengupayakan perubahan itu. Kerangka konseptual yang mengarah kepada perlindungan 
dan pelestarian lingkungan sangat diperlukan, dan materi-materi yang mempertegas pentingnya melakukan begitu.

Komponen afektif merupakan faktor yang membantu dalam definisi sikap. Hal ini dapat dilihat sepanjang kegiatan proyek ekologi (catatan lapangan) serta dalam wawancara. Dalam kedua kasus, tercatat komentar mahasiswa tentang keindahan estetika lokasi proyek pada umumnya walaupun ekosistemnya mengalami degradasi, atau untuk beberapa organisme pada khususnya, terutama orga-nisme pantai. Ada juga komentar tidak senang terhadap faktor-faktor lingkungan yang paling mem-pengaruhi ekosistem. Hal ini mungkin cara belajar yang dilakukan oleh subyek memiliki pengaruh terhadap keberhasilan tidaknya sikap dari proses belajar. Hal ini diperkuat oleh adanya mahasiswa kelompok eksperimen yang menggunakan informasi pengetahuan yang relevan untuk menentukan sikapnya terhadap lingkungan. Adanya sikap dan perilaku yang tidak sesuai dimungkinkan terpengaruh oleh pengetahuan lingkungan tambahan yang diperolehnya dari luar.

Hasil penelitian ini harus menyebutkan bahwa sikap mempengaruhi perilaku, walalupun sepenuhnya tidak berpengaruh mutlak dalam menentukan perilaku, apalagi dalam jangka panjang. Pendidikan lingkungan adalah interdisipliner, oleh karenanya penting untuk mengetahui apakah sikap-sikap tersebut dapat ditingkatkan, sehingga perlu penelitian lebih lanjut untuk dikembangkan dengan skala proyek dan lokasi yang lebih luas dan kompleks. Jika hal ini dapat tercapai, membentuk sikap dan perilaku mahasiswa sebagai agen pelindung dan pelestari lingkungan dapat memberikan dampak yang lebih efisien dan efektif untuk mengurangi kerusakan di muka Bumi ini. Jalinan kerja sama dengan berbagai instansi terkait dan masyarakat harus lebih intensif, karena pelibatan dan kontribusi banyak pihak adalah kunci menuju pencapaian tujuan akhir.

\section{SIMPULAN}

Berdasarkan hasil penelitian dapat disimpulkan bahwa tingkat penguasaan keterampilan meneliti mahasiswa Program Studi Pendidikan Biologi di Wilayah III Cirebon termasuk kategori kurang. Keterampilan merancang, melaksanakan dan melaporkan penelitian tercapai berturut-turut pada angka $51,3 \%, 55,2 \%$, dan 62,8\%. Praktikum biologi yang dilakukan kurang memberikan pelatihan keterampilan meneliti kepada mahasiswa. Sekitar 43,8\% dosen praktikum yang memberikan pembekalan keterampilan meneliti. Keterampilan meneliti mahasiswa S-1 Program Studi Pendidikan Biologi se-Wilayah III Cirebon masih tergolong kategori kurang.

\section{UCAPAN TERIMA KASIH}

Ucapan terima kasih kami sampaikan kepada Kementerian Agama Republik Indonesia yang telah mendukung pendanaan penelitian ini. Begitu juga kepada pihak-pihak terkait yang tidak bisa disebutkan satu per satu dalam penyampaiannnya, diucapkan terima kasih atas segala bantuannya, semoga Allah SWT membalas kebaikannya.

\section{DAFTAR PUSTAKA}

Aldulaimi, S. H. (2016). Fundamental Islamic perspective of work ethics. Journal of Islamic Accounting and Business Research, 7(1), 59-76. https://doi.org/10.1108/JIABR-02-2014-0006

Aloysius, D. C. (2016). Pembelajaran Biologi di Indonesia bukan untuk hidup. Proceeding Biology Education Conference, 13(1), 8-22. https://jurnal.uns.ac.id/prosbi/article/viewFile/5640/5008

Anderson, J., \& Priest, C. (2012). The live education of an architect: John Hejduk and Oxford Brookes year one live projects. Journal for Education in the Built Environment, 7(2), 50-62. https://doi.org/10.11120/jebe.2012.07020050

Bazeley, P. (2010). Conceptualising research performance. Studies in Higher Education, 35(8), 889903. https://doi.org/10.1080/03075070903348404

Bybee, R. W. (2009). The BSCS 5E instructional model and 21st Century skills. BSCS.

Chu, S., Lo, C., Chow, K., Mak, M., Ho, E., \& Tsang, A. (2008). Primary four students' development of research skills through inquiry-based learning projects. The World Association of Lesson
Studies
International
Conference
2007 ,
$1-29$.

https://web.edu.hku.hk/f/acadstaff/447/2007_primary_research.pdf 
Davidson, Z. E., \& Palermo, C. (2015). Developing research competence in undergraduate students through hands on learning. Journal of Biomedical Education, 2015, 1-9. https://doi.org/10.1155/2015/306380

Gobaw, G. F., \& Atagan, H. I. (2016). Assessing laboratory skills performance in undergraduate biology students. Academic Journal of Interdisciplinary Studies, 5(3), 113-122. https://doi.org/10.5901/ajis.2016.v5n3p113

Hammersley, M. (1993). On the teacher as researcher. Educational Action Research, 1(3), 425-445. https://doi.org/10.1080/0965079930010308

Kapon, S. (2016). Doing research in school: Physics inquiry in the zone of proximal development. Journal of Research in Science Teaching, 53(8), 1172-1197. https://doi.org/10.1002/tea.21325

Karamustafaoğlu, S. (2011). Improving the science process skills ability of science student teachers using I diagrams. Eurasian Journal of Physics and Chemistry Education, 3(1), 26-38. http://www.ijpce.org/index.php/IJPCE/article/view/99

Leeming, F. C., Dwyer, W. O., Porter, B. E., \& Cobern, M. K. (1993). Outcome research in environmental education: A critical review. The Journal of Environmental Education, 24(4), 821. https://doi.org/10.1080/00958964.1993.9943504

Leonard, L. (2016). Kompetensi tenaga pendidik di Indonesia: Analisis dampak rendahnya kualitas SDM guru dan solusi perbaikannya. Formatif: Jurnal Ilmiah Pendidikan MIPA, 5(3), 192-201. https://doi.org/10.30998/formatif.v5i3.643

Loveys, B. R., Kaiser, B. N., Mcdonald, G., Kravchuk, O., Gilliham, M., Tyerman, S., \& Able, A. J. (2014). The development of student research skills in second year plant biology. International Journal of Innovation in Science and Mathematics Education, 22(3), 15-25. https://openjournals.library.sydney.edu.au/index.php/CAL/article/view/8257

Peraturan Menteri Pendidikan dan Kebudayaan Nomor 22 tahun 2016 tentang standar proses pendidikan dasar dan menengah, (2016).

Peraturan Menteri Pendidikan dan Kebudayaan Republik Indonesia nomor 65 tahun 2013 tentang standar proses pendidikan dasar dan menengah, Pub. L. No. 65 (2013).

OECD. (2019). OECD to publish results of latest PISA survey. OECD.Org. https://www.oecd.org/newsroom/oecd-to-publish-results-of-latest-pisa-survey-on-3-december2019.htm

Pratiwi, I. (2019). Efek program PISA terhadap kurikulum di Indonesia. Jurnal Pendidikan Dan Kebudayaan, 4(1), 51. https://doi.org/10.24832/jpnk.v4i1.1157

Szostak, R. (2013). Research skills for the future: An interdisciplinary perspective. Journal of Research Practice, 9(1), 1-5. http://jrp.icaap.org/index.php/jrp/article/view/385

TIMSS, \& PIRLS. (2019). Result PIRLS database lates a test news. Timssandpirls.Bc.Edu. https://timssandpirls.bc.edu/

Wahyudi, A., Marjono, M., \& Harlita, H. (2015). Pengaruh problem based learning terhadap keterampilan proses sains dan hasil belajar biologi siswa kelas X SMA Negeri Jumapolo tahun pelajaran 2013/2014. Bio-Pedagogi: Jurnal Pembelajaran Biologi, 4(1), 5-11. https://jurnal.uns.ac.id/pdg/article/view/5350

Williams, C. (2011). Research methods. Journal of Business \& Economics Research (JBER), 5(3), 6572. https://doi.org/10.19030/jber.v5i3.2532

$\mathrm{Wu}, \mathrm{M}$. (2011). Using PISA and TIMSS mathematics assessments to identify the relative strengths of students in western and Asian countries. Journal of Research in Education Sciences, 56(1). http://rportal.lib.ntnu.edu.tw/handle/20.500.12235/11643 